\title{
POLD1 Gene Mutation
}

National Cancer Institute

\section{Source}

National Cancer Institute. POLD1 Gene Mutation. NCI Thesaurus. Code C131798.

A change in the nucleotide sequence of the POLD1 gene. 